\title{
EFEKTIFITAS WEB CLME (CONTEXTUAL LEARNING MANGROVE EDUTOURISM) UNTUK MENGEMBANGKAN KARAKTER PEDULI LINGKUNGAN PADA SISWA SMA
}

\author{
Sekar Jati Pamungkas ${ }^{1 *}$, Muhammad Radian N.A ${ }^{2}$, Alifia Rizka \\ Fitrianti $^{3}$
}

Universitas $\operatorname{Tidar}^{1,2,3}$

*Corresponding Author: sekardjati@untidar.ac.id

DOI: 10.24929/lensa.v10i2.125

Received: 11 November 2020 Revised: 25 November 2020 Accepted: 25 November 2020

\begin{abstract}
Kerusakan mangrove di kawasan Demang Gedi, Purwodadi, Purworejo yang disebabkan sebagian besar oleh tangan manusia dikarenakan kurangnya kepedulian terhadap lingkungan. Karakter peduli lingkungan perlu dibangun sejak dini, maka diperlukan sebuah upaya untuk menanamkan karakter peduli terhadap lingkungan. Karakter peduli lingkungan dapat dibentuk melalui contextual learning mangrove edutourism. Melalui Aplikasi Contextual Learning Mangrove Edutourism (CLME) ini diharapakan dapat menanamkan karakter peduli terhadap lingkungan sejak dini, karena tujuan dari contextual learning mangrove edutourism ini yaitu memotivasi peserta didik di SMA pesisir pantai sekitar Purwodadi agar lebih memahami suatu materi yang dipelajarinya dengan menerapkan apa yang dipelajarinya dengan kehidupan sehari hari. Pada era revolusi industri 4.0 ini, untuk mempermudah penanaman karakter peduli terhadap lingkungan peserta didik SMA di pesisir pantai, maka peneliti tertarik untuk membuat Aplikasi Contextual Learning Mangrove Edutourism (CLME) untuk mengembangkan karakter peduli lingkungan pada peserta didik SMA di kawasan tersebut. Tujuan penelitian adalah (a) mengembangkan karakter peduli lingkungan melalui aplikasi contextual learning mangrove edutourism (CLME), (b) mengukur karakter peduli lingkungan setelah menggunakan aplikasi contextual learning mangrove edutourism (CLME). Penelitian ini menggunakan metode pengembangan ( $R \& D$ ) atau 4-D yang mana terdiri dari 4 tahapan: define, design, develop dan disseminate. Dari penelitian pengembangan karakter peduli lingkungan melalui aplikasi contextual learning mangrove edutourism (CLME). Terdapat lima data yang digunakan meliputi: (1) Penilaian Sikap Peduli Lingkungan (Teman Sebaya) mendapatkan rerata skor 4 (sangat setuju), (2) Penilaian Sikap Peduli Lingkungan (Observer) mendapatkan rerata skor 4 (sangat setuju), (3) Tanggapan Siswa Mengenai Pembelajaran Biologi Melalui CLME mendapatkan rerata skor 4 (sangat setuju), (4)Tanggapan Siswa Mengenai Kepedulian Lingkungan mendapatkan rerata skor 4 (sangat setuju) dan (5) Penilaian Web CLME Oleh Dosen Ahli, Praktisi Dan Peer Reviewer Sedangkan untuk penilain Web CLME oleh dosen ahli, praktisi, dan peer reviewer masing masing aspek mendapatkan rerata dalam kategori baik dan sangat baik. Berdasarkan data diatas maka Contextual Learning Mangrove Edutourism dapat membentuk karakter peduli lingkungan peserta didik.
\end{abstract}

Kata kunci: contextual learning, mangrove, edutourism, karakter peduli lingkungan

\section{ABSTRACT}

Mangrove forests damage in the Demang Gedi area, Purwodadi sub-district, Purworejo regency of Central Java has been caused mostly by the human due to their less concern for the living environment. The character of caring for the environment needs to be built from an early age, so there must be specific efforts to form a strong character to take care of the environment. Environmental care character can be formed through contextual learning mangrove edutourism. Through the Contextual Learning Mangrove Edutourism, it is expected that the character of caring for the environment can be instilled as early as possible because the purpose of this contextual learning mangrove edutourism is to motivate the students in coastal high schools around Purwodadi to better understand the meaning of the subject matters they are learning by linking the materials with the context of their daily lives. In the current 4.0 industrial revolution era, with the aim of facilitating the development of environmental care characters for high 
school students on the coast, the researchers are interested in creating contextual learning mangrove edutourism application to develop the environmental care characters for high school students in the area. The research objectives are (a) to develop the character of environmental care through the application of contextual learning mangrove edutourism (CLME), and (b) to measure the character of caring for the environment after using the contextual learning mangrove edutourism (CLME) application. This research uses a development method ( $R \& D)$ using a 4-D model which includes some stages; define, design, develop, and disseminate. The research on the character development of environmental care through the application of contextual learning mangrove edutourism (CLME) covers five primary data: (1) Assessment of Environmental Care Attitudes (Peers) with the average score of 4 (strongly agree); (2) Assessment of Environmental Care Attitudes (Observer) with the average score of 4 (strongly agree); (3) Response Students regarding Biology Learning through CLME with the average score of 4 (strongly agree); (4) Student Responses Regarding Environmental Concern with the average score of 4 (strongly agree), and; (5) CLME Web Assessment by Expert Lecturers, Practitioners, and Peer Reviewers, where each aspect is classified as good and very good. Based on the data above, the Contextual Learning Mangrove Edutourism can form the character of caring for the environment of the students.

Keywords: contextual learning, mangrove, edutourism, the character of caring for the environment

\section{PENDAHULUAN}

Wilayah Pesisir Demang Gedi, Purwodadi, Purworejo terletak diwilayah dekat dengan laut jawa bagian selatan maka dari itu wilayah ini disebut wilayah pesisir pantai. Wilayah pesisir dicirikan sebagai daerah pemisah antara lautan dan daratan. Bagian darat dicirikan sebagai daerah yang masih dipengaruhi oleh sifat sifat laut seperti angin laut,dan pasang surut air laut (Tefarani, 2019). Sedangkan wilayah laut ini juga memiliki ciri ciri yang masih dipengaruhi sifat daratan seperti adanya sendimentasi maupun aliran air tawar (Trinanda, 2017). Masalah utama di negara tropis dan subtropis yang menyangkut wilayah pesisir adalah terjadinya bencana erosi, dan kerusakan hutan bakau. Apabila hal ini terjadi terus menerus dan konsisten maka dapat mengakibatkan hilangnya lahan pertanian sehingga akan berdampak pada penurunan ekonomi masyarakat pesisir. Selain itu potensi kehilangan tempat tinggal juga mengancam masyarakat di pesisir pantai. (Akbar, 2017).

Salah satu pencegahan dari kerusakan wilayah pesisir pantai yaitu dengan menjaga ekosistem mangrove yang ada di dekat bibir pantai. Ekosistem hutan mangrove memiliki fungsi yang sangat krusial untuk wilayah pesisir. Fungsi utama dari ekosistem mangrove adalah menjembatani antara wilayah darat dengan wilayah laut, serta peredam gejala gejala yang terjadi di alam, seperti abrasi, maupun gelombang.(Mappanganro, 2020). Habitat mangrove juga berfungsi sebagai sumber nutrien bagi organisme laut seperti kepiting, udang maupun ikanikan kecil. Habitat ini juga digunakan untuk tempat berlindung maupun berkembang biak biota laut Mengingat pentingnya habitat mangrove dalam mempertahankan daerah pesisir, maka perlu adanya edukasi kepada masyarakat maupun pengunjung untuk menjaga dan merehabilitasi mangrove yang rusak (Mu'alimah, 2019).

Perlu adanya tindakan nyata untuk mencegah kerusakan daerah pesisir yaitu salah satunya dengan menjaga kelestarian ekosistem mangrove di Demang Gedi. Umumnya hutan mangrove memiliki beberapa fungsi antra lain: mencegah pantai dari bencana erosi dengan tetap menjaga garis pantai untuk stabil, selain itu fungsi lainya adalah menahan tiupan angin kencang dari arah laut ke darah serta mencegah sendimentasi (Majid, 2016). Dewasa ini mangrove belum banyak dimanfaatkan dari segi pendidikan. Pemanfaatan kawasan hutan mangrove sebagai tempat wisata pendidikan menjadikan mangrove memiliki daya tarik tersendiri. Edutourism dapat mendorong tidak hanya dari pelajar tapi juga dapat menarik minat wisatawan melakukan proses belajar secara langsung.

Negara indonesia menyumbang sekitar $19 \%$ dari total hutan mangrove dunia. Tetapi dilansir dari Kementerian Lingkungan Hidup dan Kehutanan atau singkatnya (KLHK) menyatakan bahwa sekitar 1,81 juta hektare mangrove mengalami kerusakan. 
Kejadian tersebut mayoritas disebabkan oleh ulah manusia yang tidak bertanggung jawab. Akibatnya hanya tersisa sekitar 1,67 juta hektare hutan mangrove yang masih dalam kondisi baik dan terjaga. Mayoritas Kerusakan mangrove terjadi akibat ulah tangan manusia dikarenakan kurangnya kepedulian terhadap lingkungan. Kurangnya kepedulian terhadap lingkungan dikarenakan tidak adanya karakter peduli terhadap lingkungan.

Karakter peduli terhadap lingkungan ini perlu dibangun sedini mungkin, maka diperlukan sebuah upaya untuk memupuk dan membangun karakter peduli terhadap lingkungan. Menurut perdana 2018 Karakter peduli terhadap lingkungan dapat dibentuk melalui contextual learning mangrove edutourism. Melalui contextual learning mangrove edutourism ini diharapakan karakter peduli lingkungan dapat ditanamkan secara dini, karena tujuan dari contextual learning mangrove edutourism ini yaitu memotivasi peserta didik di SMA sekitar kawasan Demang Gedi untuk dapat memahami serta menerapkan apa yang telah didapatkanya di sekolah maupun diluar sekolah dengan cara mengaitkan hal tersebut dengan kehidupan sehari-hari. Pada era revolusi industri 4.0 ini karakter peduli terhadap lingkungan dapat dengan mudah ditanamkan kepada peserta didik SMA di pesisir pantai, maka peneliti tertarik untuk membuat sebuah aplikasi berbasis contextual learning (pembelajaran kontekstual) mangrove edutourism untuk menanamkan serta mengembangkan karakter peduli terhadap lingkungan pada peserta didik SMA di kawasan Demang Gedi.

1. Pembelajaran berbasis konteks (pembelajaran kontekstual)

Pembelajaran berbasis konteks adalah sebuah konsep yang menyatakan bahwa materi yang diajarkan disekolah dapat dikaitkan dengan kehidupan nyata sehingga dapat membantu siswa menerapkan apa yang diketahuinya di sekolah dengan kehidupan nyata. (Ramdani, 2018). Pembelajaran dengan metode ini akan menimbulkan suasana belajar yang nyaman dan aktif, siswa akan menyelidiki mengenai suatu hal kemudian bekerja sama dengan siswa lainya untuk memahami serta memecahkan masalah yang ada kemudian menerapkanya dikehidupan sehari hari (Muchtar et al., 2019). Santoso (2017) menyatakan bahwa pembelajaran kontekstual melibatkan tujuh komponen, antara lain:

a) Konstruktivisme

Secar harfiah kontruktivisme berarti membangun. Sehingga dapat diartikan bahwa kontruktivisme meruakan proses membangun pengetahuan siswa berdasarkan pengalaman yang dialami siswa sendiri. Pembelajaran semacam ini akan membantu siswa dalam mengingat materi materi yang diberikan dengan baik

b) Inkuiri

Kunci dari pembelajaran inkuiri terletak pada proses berpikir yang sistematis. Sehingga siswa akan terbiasa berpikir secara ilmiah dan terstruktur dalam berpikir.

c) Bertanya

Bertanya merupakan indikasi dari keingintahuan seseorang. Kegiatan bertanya ini dapat membantu siswa untuk berpikir kritis serta mengemukakan sesuatu yang di anggapnya belum jelas. Pembelajaran kontekstual memberikan jembatan kepada guru untuk meminta respon dari siswa terhadap apa yang diberikanya.

d) Masyarakat belajar

Masyarakat belajar artinya melakukan kerjasama dengan orang lain baik perseorangan maupun kelompok dalam proes pembelajaran. Proses ini akan menghasilkan suatu pengetahuan baik dari sharing maupun memberikan pengalaman dengan siswa lainya

e) Pemodelan

Proses ini berkaitan dengan pemberian contoh atau memperagakan sesuatu kemudian di tiru oleh siswa.Proses ini tidak terbatas hanya dari guru saja, melainkan dapat dari yang dianggap memiliki kemampuan lebih.

f) Refleksi 
Refleksi merupakan suatu proses bercermin dengan cara mengurutkan proses proses terdahulu secara sistematis. Refleksi biasanya di laksanakan pada akhir pembelajaran.

g) Penilaian autentik

Penilaian autentik merupakan suatu proses yang dilakukan pendidik sebagai upaya untuk mengumpulkan suatu informasi mengenai perkembangan pengetahuan, sikap serta proses berpikir siswa. Dalam pembelajaran kontekstual, penilaian autentik tidak hanya menekankan pada hasil belajr saja melainkan proses mencapai hasil pembelajaran

\section{Ekosistem Mangrove}

Ekosistem mangrove merupakan suatu daerah yang terdiri komponen hidup atau biotik dan komponen tak hidup atau abiotik yang khas. Komponen biotik terdiri dari vegetasi mangrove, maupun fauna yang hidup dalam ekosistem tersebut seperti kepiting dll. komponen abiotik terdiri dari lumpur, air dan udara. Vegetasi mangrove ini tidak dapat digantikan dengan vegetasi lainya karena strukturnya sangat khas. Mangrove biasanya hidup di daerah berlumpur maka dari itu dibutuhkan proses adaptasi agar mangrove tetap tumbuh dengan optimal. Adaptasi yang terjadi biasanya berkaitan dengan sistem perakaran, bunga dan vegetasi mangrove dapat membentuk pola serta zonasi tertentu (Schaduw, 2018).

Ekosistem mangrove berada di daerah peralihan antara daratan dan lautan. Hal ini mengakibatkan ekosistem mangrove kaya akan keanekaragaman hayati. Hal ini pad awalnya menjadikan keuntungan bagi manusia yang tinggal dikawasan sekitar mangrove, tetapi dewasa ini kawasan mangrove semakin dieksploitasi, apabila kegiatan ini terjadi terus menerus maka akan mengakibatkan kerusakan kawasan mangrove. Keruskan kawasan mangrove akan berdampak hilangnya garis pantai sehingga potensi terjadinya abrasi akan semakin meningkat. Perlu adanya suatu usaha untuk memelihara kawasan hutan mangrove dari ancaman kerusakan dengan tetap memperhatikan fungsi kesinambungan hutan mangrove (Martuti, dkk, 2018).

\section{Edutourism}

Pengertian Edutourism menurut Sulistisana (2018) adalah perjalanan wisata dengan menyelipkan nilai nilai edukasi, jadi seseorang tidak hanya sekedar berwisata tetapi juga mendapatkan pengetahuan mengenai hal tersebut. Kegiatan berwisata pendidikan (edutourism) ini merupakan proses belajar sepanjang hidup (Mahadewi, 2018). Sedangkan menurut Pitaloka (2019) menyatakan bahwa edutourism ini mengacu pada setiap program wisataatau rekreasi dimana seseorang akn melakukan perjalanan ke tempat tertentu yang bertujuan untuk mendapatkan pengalaman belajar.

Dalam kegiataneutourism, sseorang akan banyak berinteraksi dengan orang lain yang memiliki latar belakang dan kepentingan yang beragam dengan adanya berbagai perbedaan tersebut, diharapkan terdapat pertukaran berbagai informasi dan kepentingan yang nantinya dapat memberikan warna tersendiri bagi wisata pendidikan.(Akhmedova,2016)

Pelaksanaan edutourism memberikan berbagai manfaat bagi pihak-pihak yang terlibat dalam penyelenggaraan pariwisata. Manfaat yang dapat diperoleh dari pelaksanaan edutourism antara lain:

a. Menarik banyak konsumen yang kurang puas dengan liburan "paket".

b. Memiliki potensi untuk menciptakan produk pariwisata yang berkelanjutan secara sosial dan ekonomi yang bermanfaat bagi kawasan wisata maupun pengunjungnya.

c. Dapat membantu meremajakan pariwisata di seluruh dunia.

d. Memberikan peluang yang lebih bermakna bagi masyarakat dan pengunjung. (International career studies, 2013)

4. Karakter Peduli Lingkungan 
Menurut Tamara (2016) menyatakan bahwa "sikap peduli terhadap lingkungan merupakan wujud nyata upaya diri baik sikap maupun tindakan untuk menjaga serta memelihara lingkungan dari ancaman kerusakan"

Pusat Kurikulum Kementerian Pendidikan Nasional menetapkan pendidikan karakter terhadap lingkungan menjadi salah satu dari 18 karakter. Karakter peduli terhadap lingkungan dideskripsikan sebagai suatu sikap maupun tindakan untuk mencegah kerusakan lingkungan (Sukron, 2017). Sedangkan menurut Noviani (2015) Karakter peduli terhadap lingkungan merupakan pencegahan kerusakan lingkungan serta pengembangan upaya perbaikan kerusakan alam yang sudah terjadi. Pendidikan karakter merupakan proses pendidikan secara keseluruhan yang dialami oleh peserta didik yang diartikan sebagai pengalaman pembetukan kepribadian melalui pemahaman serta pengalaman sendiri mengenai nilai-nilai tersebut. (Hastutiningsih, 2016).

Karakter peduli terhadap lingkungan bukan merupakan karakter bawaan tetapi mrupakan hasil dari suatu proses pendidikan yang konsisten. Kesalahan yang terjadi saat pembelajaran dapat menjadikan penanaman karakter ini tidak berjalan dengan optimal. Maka dari itu penanaman karakter haruslah dibentuk kepada setiap individu sedini mungkin, sehingga setiap individu dapat memaknai setiap tindakan dan perilakunya. (Iswari,2017)

\section{METODE}

Penelitian ini menggunakan model peneletian pengembangan (research and development atau biasa disebut R\&D). Produk yang dikembangkan adalah Aplikasi Contextual Learning Mangrove Edutourism (CLME). Tujuan dari pengembangan produk ini adalah untuk menanamkan serta mengembangkan karakter peduli terhadap lingkungan di SMA Pesisir Pantai. Model yang digunakan untuk dasar pengembangan Aplikasi Contextual Learning Mangrove Edutourism (CLME) ini merupakan hasil adaptasi dari pengembangan perangkat model 4-D oleh Thiagarajan (1974).

Mekanisme Pengembangan dalam penelitian ini mengadopsi dari penelitian pengembangan perangkat model 4-D (four $D$ model) yang dikemukakan oleh Thiagarajan. Model ini terdiri dari 4 tahap pengembangan, yaitu Define, Design, Develop, dan Disseminate. Mekanisme pengembangan penelitian ini di jabarkan pada Bagan 1. 


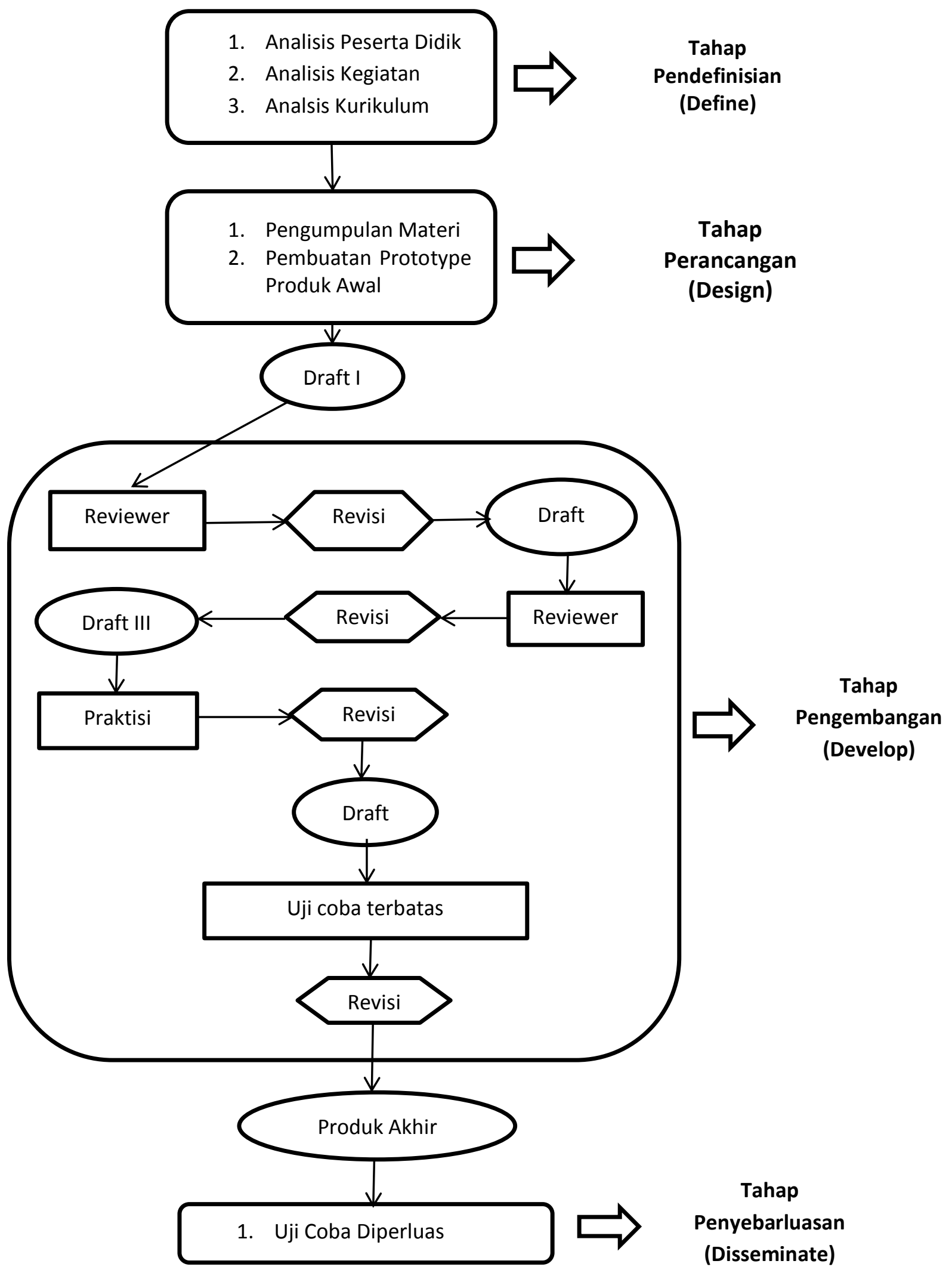

Gambar 1. Bagan Alur Penyusunan Aplikasi Contextual Learning Mangrove Edutourism (CLME) Diadaptasi dari Thiagarajan, 1974 
Uji Coba Produk Aplikasi Contextual Learning Mangrove Edutourism (CLME) meliputi kegiatan validasi, uji coba terbatas, dan uji coba lapangan. Penjelasan lebih rinci untuk uji coba produk CLME adalah sebagai berikut:

a. Desain Uji Coba

Uji Coba Aplikasi Contextual Learning Mangrove Edutourism (CLME) dalam penelitian ini menggunakan beberapa jenis penelitian, yaitu:

1) Validasi Aplikasi CLME menggunakan penelitian deskriptif kualitatif. Produk yang telah jadi kemudian disusun dan selanjutnya akan divalidasi oleh reviewer. Penilaian produk ditinjau dari aspek kelayakan isi (materi), aspek penyajian, aspek kebahasaan, dan aspek kegrafisan. Penilaian ini menggunakan lembar angket yang berisi tentang pemberian nilai setiap aspek dan pemberian saran dan masukan terhadap produk yang dikembangkan.

2) Uji Coba Terbatas merupkan uji coba yang bertujuan untuk mengetahui keefektifan aplikasi CLME dalam mengembangkan karakter peduli lingkungan. Uji coba terbatas dilakukan untuk mengevaluasi aplikasi CLME. Teknik yang digunakan dalam uji coba ini yaitu teknik observasi. Data yang diperoleh dari lembar observasi tersebut kemudian dianalisis secara deskriptif.

3) Uji coba lapangan aplikasi CLME menggunakan penelitian eksperimen one shoot case study. Uji coba lapangan ini bertujuan untuk mengetahui sebuah kualitas aplikasi CLME dalam mengembangkan karakter peduli lingkungan.

b. Subjek Uji Coba

Subjek untuk masing-masing tahap uji coba aplikasi CLME adalah sebagai berikut:

1) Validator untuk aplikasi CLME terdiri dari 2 orang dosen ahli (ahli media dan ahli materi), dan 2 orang praktisi (guru Biologi SMA).

2) Subjek untuk uji coba terbatas terdiri dari 15 orang siswa SMA pesisir pantai. 3) Subjek untuk uji coba lapangan yaitu siswa 2 SMA di pesisir pantai.

3) Subjek untuk uji coba lapangan yaitu siswa 2 SMA di pesisir pantai. Pengambilan sampel ini dilaksanakan secara purposive sampling dengan jumlah sampel sebanyak 56 siswa (2 kelas) masing-masing SMA di 2 SMA yang berbeda yang letaknya di dekat pesisir pantai.

c. Jenis Data

Jenis data untuk masing-masing tahap uji coba aplikasi CLME adalah sebagai berikut:

1) Data hasil validasi berupa kritik dan saran terhadap aplikasi CLME adalah data kualitatif, sedangkan data hasil penilaian produk merupakan data kuantitatif.

2) Data hasil evaluasi teknis pelaksanaan uji coba terbatas aplikasi CLME merupakan data kualitatif.

3) Jenis data hasil uji coba lapangan adalah sebagai berikut:

a) Data ketercapaian karakter peduli lingkungan merupakan data kualitatif.

b) Data tanggapan siswa merupakan data kuantitatif.

d. Instrumen Pengumpulan Data

Jenis data untuk masing-masing tahap uji coba aplikasi CLME adalah sebagai berikut:

1) Instrumen untuk tahap validasi adalah angket. Masing-masing produk dinilai dengan satu angket yang terdiri dari empat aspek penilaian, yaitu aspek kelayakan terhadap isi, penyajian, kebahasaan, serta kegrafisan. Penilaian produk menggunakan skala 5.

2) Instrumen untuk uji coba terbatas adalah lembar observasi.

3) Instrumen untuk uji coba lapangan adalah sebagai berikut: 
a) Instrumen ketercapaian karakter peduli lingkungan berupa lembar observasi karakter peduli lingkungan. Lembar observasi ini menggunakan penilaian skala 4.

b) Instrumen tanggapan siswa menggunakan angket

e. Teknik Analisis Data

Teknik analisa data merupakan salah suatu langkah yang menentukan dari keberhasilan suatu penelitian, hal itu disebabkan karena alisis data berfungsi untuk menyimpulkan hasil penelitian. (Sugiyono, 2017). Teknik analisis data untuk masing-masing tahap uji coba aplikasi CLME adalah sebagai berikut:

1) Data hasil validasi berupa kritik dan saran dianalisis secara deskriptif dengan disarikan untuk memperbaiki produk yang dikembangkan. Analisis deskriptif merupakan analisis yang mendeskripsikan dan menjelasan mengenai rumusan masalah.(Bungin,2015). Data hasil validasi dinyatkan dalam bentuk skor yang kemudian akan dianalisis menggunakan statistik deskriptif untuk mencari rerata dan skor total. Perhitungan tersebut didasarkan pada skor-skor yang diperoleh berdasarkan penilaian skala 5 . Kriteria penilaian yaitu: (5) sangat baik, (4)baik, (3) cukup baik, (2)kurang baik, (1) sangat kurang baik.

2) Data hasil uji coba terbatas mengenai aplikasi CLME dianalisis secara deskriptif dengan disarikan untuk memperbaiki produk yang dikembangkan.

3) Data hasil uji coba lapangan ada beberapa jenis, maka analisis data disesuaikan dengan masing-masing jenis data. Penjelasan teknik analisis data untuk data hasil uji coba lapangan adalah sebagai berikut:

a) Analisis ketercapaian karakter peduli lingkungan Analisis ketercapaian karakter peduli lingkungan dilakukan dengan melakukan konversi total skor menjadi nilai dengan skala 4.

b) Analisis tanggapan siswa Data tanggapan siswa dianalisis dengan mengkonversi data tanggapan menjadi nilai skala 4 sama seperti analisis karakter peduli lingkungan

\section{HASIL DAN DISKUSI}

Terdapat lima data yang digunakan meliputi: (1) Penilaian Sikap Peduli Lingkungan (Teman Sebaya), (2) Penilaian Sikap Peduli Lingkungan (Observer), (3) Tanggapan Siswa Mengenai Pembelajaran Biologi Melalui CLME, (4)Tanggapan Siswa Mengenai Kepedulian Lingkungan dan (5) Penilaian Web CLME Oleh Dosen Ahli, Praktisi Dan Peer Reviewer. Dari data tersebut, selanjutnya dianalisis secara deskriptif sebagai berikut:

1. Penilaian Sikap Peduli Lingkungan (Teman Sebaya)

Pada indikator nomor 1 "siswa tidak merusak vegetasi mangrove" memperoleh nilai rata-rata 3 jadi dapat dikategorikan siswa tersebut setuju. Pada indikator nomor 2 "apabila diperlukan dalam pengamatan, siswa mengambil sampel dari tumbuhan mangrove seperlunya saja" memberoleh nilai rata-rata 4 jadi dapat dikategorikan siswa tersebut sangat setuju. Pada indikator nomor 3 " siswa tidak membunuh fauna mangrove" memperoleh nilai rata-rata 4 jadi dapat dikategorikan siswa sangat setuju. Pada indikator nomer 4 "siswa tidak menangkap dan membawa pulang fauna mangrove" memperoleh rata-rata 4 jadi dapat dikategorikan siswa tersebut sangat setuju. Pada indikator nomor 5 "siswa tidak memindahkan fauna mangrove dari habitat asalnya" memperoleh nilai rata-rata 3 jadi dapat dikategorikan setuju. Pada indikator nomor 6 "siswa mengumpulkan sampah plastik yang ada dilingkungan mangrove" memperoleh nilai rata-rata 4 jadi dapat dikategorikan sangat setuju. Pada indikator nomor 7 "siswa tidak membuang sampah sembarangan" mendapat nilai rata-rata 4 jadi dapat dikategorikan siswa tersebut sangat setuju. Pada indikator nomor 8 "siswa melakukan penanaman 
mangrove dengan baik dan benar" mendapatkan hasil rerata 4 jadi dapat dikategorikan siswa tersebut sangat setuju. Pada indikator nomor 9 "siswa melakukan teknik penangkapan ikan dengan bijaksana" mendapatkan nilai ratarata 4 jadi dapat dikategorikan siswa tersebut sangat setuju. Pada nomor 10 "siswa melakukan perlindungan bibit mangrove yang tumbuh alami" mendapatkan nilai rata-rata 4 jadi dapat dikategorikan siswa tersebut sangat setuju

Hal tersebut dapat digambarkan dengan grafik dibawah ini:

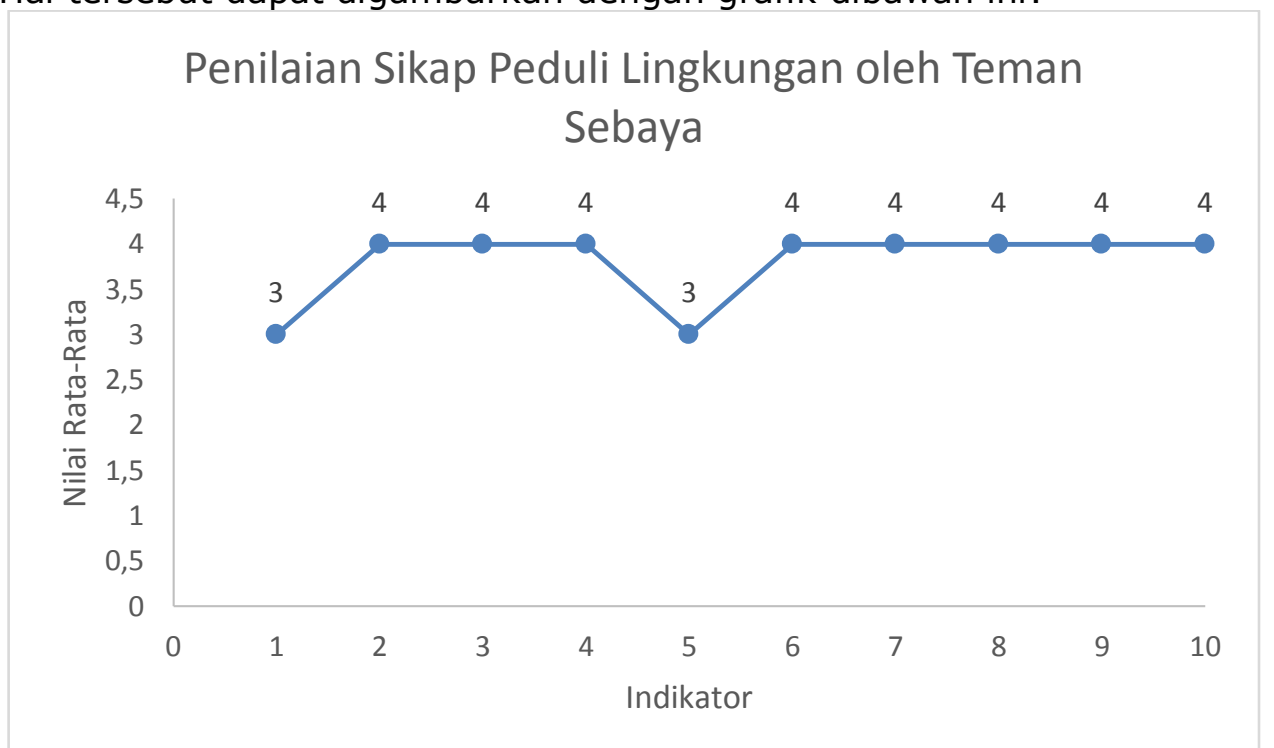

\section{Gambar 1.1 Grafik Penilaian Sikap Peduli Lingkungan (Teman Sebaya)}

\section{Penilaian Sikap Peduli Lingkungan (Observer)}

Pada indikator nomor 1 yaitu siswa tidak merusak vegetasi mangrove memiliki nilai rata-rata 4, artinya siswa sangat setuju untuk melestarikan mangrove dan tidak merusak vegetasi mangrove. Pada indikator nomor 2 yaitu apabila diperlukan dalam pengamatan, siswa mengambil sampel dari tumbuhan mangrove seperlunya saja memiki nilai rata-rata 3, artinya siswa setuju untuk mengambil sampel tumbuhan mangrove seperlunya saja saat melakukan pengamatan. Pada indikator nnomor 3 yaitu siswa tidak membunuh fauna mangrove memiliki nilai rata-rata 3, artinya siswa setuju untuk melestarikan fauna dan tidak membunuh fauna mangrove. Pada indicator nomor 4 yaitu siswa tidak menangkap dan membawa pulang fauna mangrove memiliki nilai rata-rata 3, artinya siswa setuju untuk tidak menangkap dan tidak membawa fauna pulang. Pada indikator nomor 5 yaitu siswa tidak memindahkan fauna mangrove dari habitat aslinya memiliki nilai rata-rata 4, artinya siswa sangat setuju untuk tidak memindahkan fauna dari habitat aslinya. Pada indikator nomor 6 Siswa mengumpulkan sampah plastic yang ada di lingkungan mangrove memiliki nilai rata-rata 4 artinya siswa sangat setuju untuk mengumpulkan sampah plastik yang berada di lingkunan mangrove untuk menjaga kebersihan lingkungan mangrove. Pada indikator nomor 7 yaitu siswa tidak membuang sampah sembarangan memiliki nilai rata-rata 4, artinya siswa sangat setuju untuk tidak membuang sampah sembarangan dan siswa sadar akan pentingnya kebersihan lingkungan mangrove. Pada indikator nomor 8 yaitu siswa melakukan penanaman mangrove dengan baik dan benar memiliki rata-rata nilai 4, artinya siswa sangat setuju dan dapat menanam mangrove dengan baik dan benar sesuai dengan prosedur penanaman mangrove. Pada indikator nomor 9 yaitu siswa melakukan teknik penangkapan ikan dengan bijaksana memiliki nilai rata-rata 4, artinya siswa sangat setuju untuk melakukan teknik penangkapan ikan dengan bijaksana yaitu dengan teknk-teknik yang benar dan tidak menimbulkan dampak yang buruk pada lingkungan mangrove. Indikator nomor 10 yaitu siswa melakukan perlindungan bibit mangrove yang tumbuh alami memiliki nilai rata-rata 4, artinya 
siswa sangat setuju untuk melindungi bibit mangrove yang tumbuh alami untuk menjaga kelestarian vegetasi mangrove.

Hal tersebut dapat digambarkan dengan grafik dibawah ini:

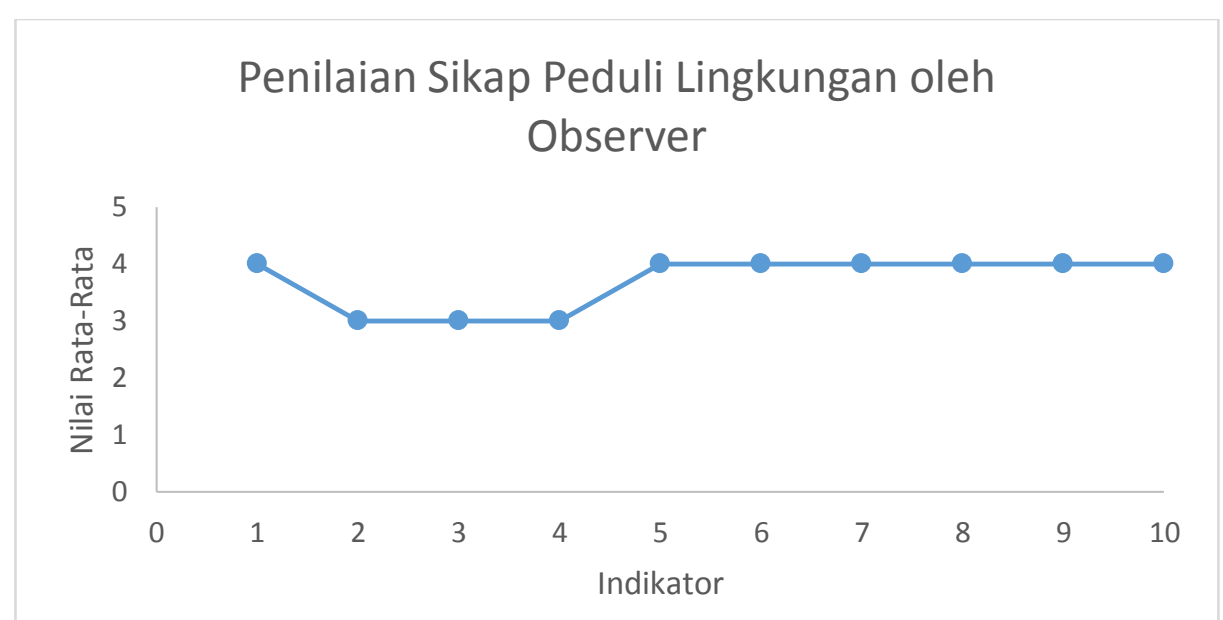

\section{Gambar 2.1 Grafik Penilaian Sikap Peduli Lingkungan (Observer)}

\section{Tanggapan Siswa Mengenai Pembelajaran Biologi Melalui CLME}

Pada indikator nomor 1 yaitu, pembelajaran melalui CLME memungkinkan siswa untuk belajar sambil berwisata, memiliki nilai rata-rata 4 dimana memiliki arti bahwa siswa sangat setuju terhadap hal tersebut. Pada indikator nomor 2 yaitu, pembelajaran melalui CLME, bagi siswa merupakan pembelajaran dengan suasana baru dan meyenangkan, memiliki nilai rata-rata 3, maka artinya leih dari sebagian siswa setuju mengenai hal tersebut. Pada indikator nomor 3, yaitu kegiatan pembelajaran melalui CLME dapat memunculkan motivasi belajar, memiliki nilai rata-rata 3, maka artinya siswa setuju. Pada indikator nomor 4, yaitu kegiatan pembelajaran melalui CLME dapat memunculkan rasa ingin tahu, memiliki nilai rata-rata 4, maka artinya siswa sangat setuju. Pada indikator nomor 5, yaitu kegiatan pembelajaran melalui CLME membantu siswa untuk memahami keterkaitan antara ekosistem mangrove dengan berbagai aspek kehidupan, memiliki nilai rata-rata 4, maka artinya siswa sangat setuju. Pada indikator nomor 6, yaitu kegiatan pembelajaran melalui CLME membantu siswa membangun pemahaman yang utuh, luas, dan memdalam mengenai segala hal tentang ekosistem mangrove, memiliki nilai rata-rata 4, maka artinya siswa sangat setuju. Pada indikator nomor 7, yaitu kegiatan pembelajaran melalui CLME memberi kesempatan melakukan penyidikan atau pengamatan langsung untuk mendapat pengetahuan, memiliki nilai rata-rata 4, maka artinya siswa sangat setuju. Pada indikator nomor 8, yaitu kegiatan pembelajaran melalui CLME memberi kesempatan untuk mengaplikasikan mengenai konsep-konsep biologi yang telah dikuasai sebelumnya untuk melihat penerapan atau kesesuainnya dilapangan, memiliki nilai rata-rata 3, maka artinya siswa setuju. Pada indikator nomor 9, yaitu kegiatan ini dapat menunjang pembelajaran biologi yang telah dilakukan disekolah khususnya mengenai materi ekosistem, mendapatkan rata-rata 4, artinya siswa sangat setuju. Pada indikator nomor 10, yaitu hal yang dipelajari melalui CLME memperkuat pemahaman mengenai materi ekosistem yang diperoleh disekolah, memiliki nilai rata-rata 4, maka artinya siswa sangat setuju.

Maka secara garis besar pembelajaran biologi melalui CLME ini diharapkan untuk lebih aktif dalam kegiatan pembelajaran. Siswa juga tidak mudah merasa jenuh karena siswa dapat belajar sambil berwisata dan juga siswa dapat belajar dalam suasana yang baru sehingga tingkat motivasi belajar siswa akan meningkat. Pembelajaran dengan CLME ini dapat menumbuhkan rasa ingin tahu siswa terhadap hal baru sehingga siswa akan semangat dalam belajar dan proses pembelajaran akan berlangsung dengan menyenangkan. Pada pembelajaran CLME, dapat 
memungkinkan siswa untuk memahami keterkaitan antara ekosistem mangrove dengan berbagai aspek kehidupan. Hal tersebut dapat melatih cara berpikir kritis siswa. Pembelajaran CLME memungkinkan siswa untuk melakukan pengamatan secara langsung sehingga dapat membangun pemahaman yang luas, utuh, kuat, dan mendalam mengenai ekosistem mangrove.

Hal tersebut dapat digambarkan dengan grafik dibawah ini:

\section{Tanggapan Siswa Terhadap Pembelajar Biologi Melalui Web CLME}

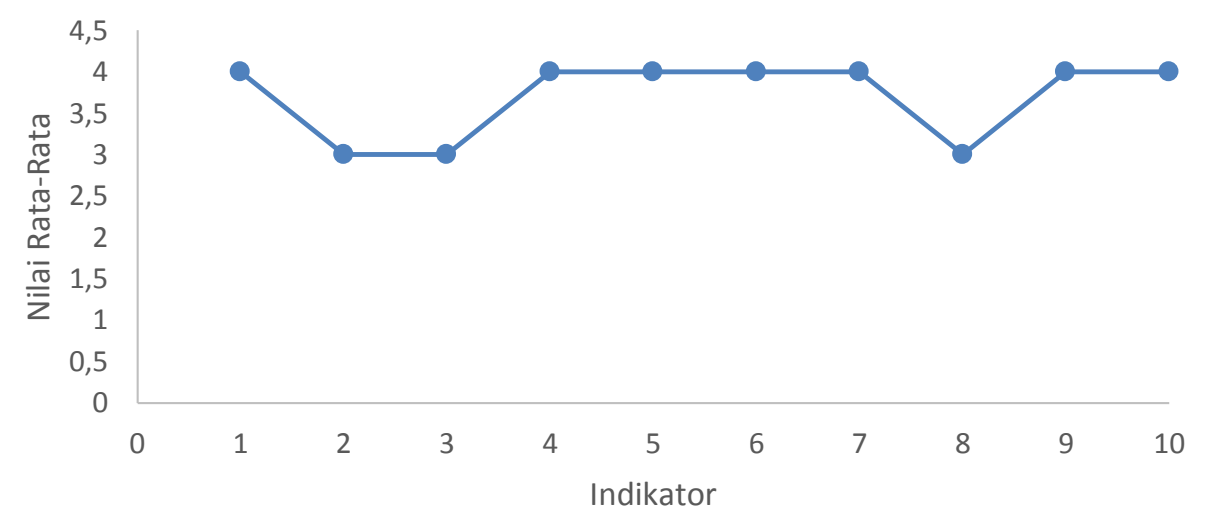

\section{Gambar 3.1 Grafik Tanggapan Siswa Mengenai Pembelajaran Biologi Melalui CLME}

4. Tanggapan Siswa Mengenai Kepedulian Lingkungan

Pada indikator nomor 1 mengenai kegiatan yang dilakukan memotivasi untuk lebih perduli terhadap lingkungan memperoleh nilai rata-rata 3, maka artinya Setuju. Pada indikator nomor 2 tentang kegiatan dilakukan membantu memahami betapa pentingnya menjaga kelestarian lingkungan memperoleh nilai rerata 4, maka siswa Sangat Setuju. Pada indikator yang nomor 3 mengenai kegiatan yang dilakukan memberi kesempatan untuk mengenal dan menerapkan pemanfaatan sumberdaya alam dengan bijaksana memperoleh nilai 4, maka siswa Sangat Setuju. Pada indikator nomor 4 mengenai kegiatan yang dilakukan memberi kesempatan untuk turut serta dalam kegiatan penghijauan memperoleh nilai 4, maka Sangat Setuju. Pada indikator nomor 5 mengenai kesadaran untuk tidak membuang sampah sembarangan selama kegiatan dilaksanakan memperoleh nilai rata-rata 4, maka artinya Sangat Setuju. Pada indikator nomor 6 mengenai tidak merusak tumbuh-tumbuhan yang ada di lokasi pembelajaran memperoleh nilai 3, maka siswa Setuju.

Pada indikator nomor 7 mengenai tidak mengganggu hewan yang ada di lokasi pembelajaran memperoleh nilai 4, maka siswa Sangat Setuju. Pada indikator nomor 8 mengenai setelah melakukan kegiatan, tidak membuang sampah sembarangan dalam kehidupan sehari-hari memperoleh nilai rata-rata 4, maka artinya Sangat Setuju. Pada indikator nomor 9 mengenai setelah melakukan pembelajaran, siswa termotivasi untuk melakukan penanaman pohon di lingkungan sekitar memperoleh nilai rata-rata 3, maka artinya Setuju. Pada indikator nomor 10 mengenai kegiatan melalui pembelajaran CLME yang telah dilakukan mampu mendorong siswa untuk lebih menghargai serta menjaga flora dan fauna yang ada di lingkungan sekitar memperoleh nilai ratarata 4 , maka artinya Sangat Setuju.

Hal tersebut dapat digambarkan dengan grafik dibawah ini: 


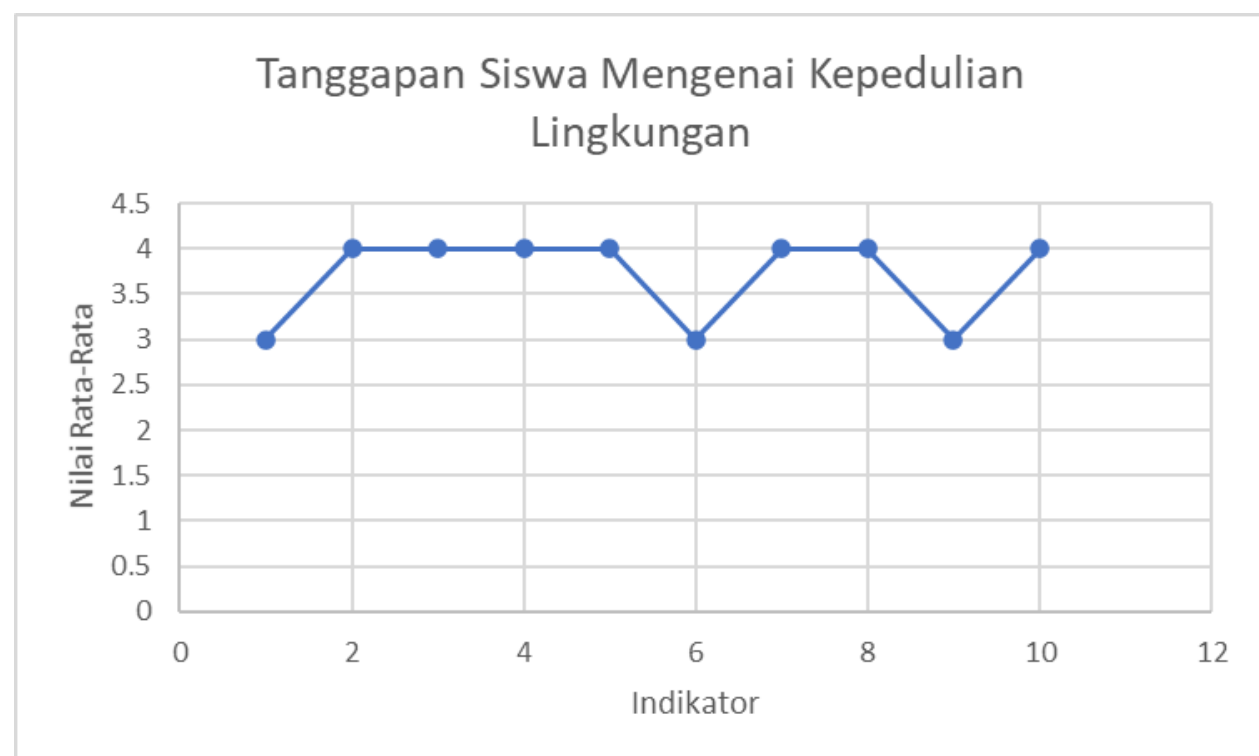

Gambar 4.1 Grafik Tanggapan Siswa Mengenai Kepedulian Lingkungan.

5. Analisis Data Hasil Validasi Web CLME

Hasil validasi Web CLME berupa kritik dan saran serta penilaian dari dosen ahli, praktisi, dan peer reviewer. Kritik dan saran dianalisis secara deskriptif kemudian ditanggapi apakah kritik dan saran tersebut diterima atau ditolak. Kritik dan saran yang ditolak maupun diterima ditanggapi dengan penjelasan yang logis. Selanjutnya, kritik dan saran yang diterima selanjutnya digunakan sebagai acuan untuk melakukan revisi produk. Hasil penilaian Web CLME ini dianalisis dengan menggunakan penilaian skala lima untuk menentukan kategori hasil penelitian produk di setiap aspeknya. Web CLME berdasarkan penilaian dosen ahli untuk aspek materi/isi memperoleh nilai rata rata skor 27 dengan kategori sangat baik, aspek penyajian memperoleh nilai rerata skor 18 dengan kategori sangat baik, aspek kebahasaan memperoleh nilai rerata skor 14 dengan kategori sangat baik, dan aspek kegrafisan memperoleh rerata skor 12 dengan kategori baik. Penilaian Web CLME oleh peer reviewer untuk aspek materi/isi memperoleh rerata skor 26,2 dengan kategori sangat baik, aspek penyajian memperoleh rerata skor 16 dengan kategori baik, aspek kebahasaan memperoleh rerata skor 11,6 dengan kategori baik, dan aspek kegrafisan memperoleh rerata skor 12 dengan kategori baik.

Secara keseluruhan, perbandingan penilaian Web CLME oleh dosen ahli, praktisi, dan peer reviewer dapat dilihat pada histogram dibawah ini:

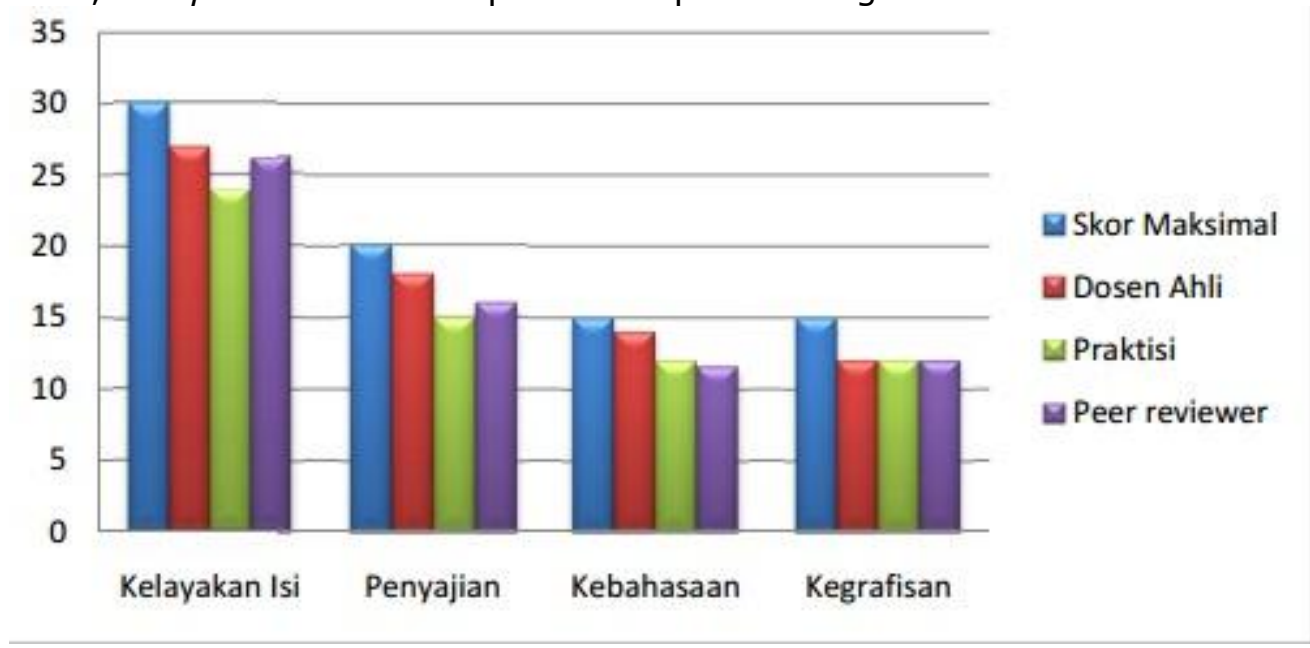

Gambar 5.1 Data Hasil Validasi Web CLME 


\section{KESIMPULAN}

Berdasarkan uraian di atas maka dapat disimpulkan bahwa Aplikasi Contextual Learning Mangrove Edutourism (CLME) terbukti dapat mengembangkan karakter peduli terhadap lingkungan pada peserta didik SMA di kawasan Demang Gedi. Hal ini dibuktikan dengan keempat grafik yang meliputi: Penilaian Sikap Peduli Lingkungan (Teman Sebaya), Penilaian Sikap Peduli Lingkungan (Observer), Tanggapan Siswa Mengenai Pembelajaran Biologi Melalui CLME dan Taanggapan Siswa Mengenai Kepedulian Lingkungan memiliki nilai yang tinggi dengan rentang 3-4. Sedangkan untuk penilain Web CLME oleh dosen ahli, praktisi, dan peer reviewer masing masing aspek mendapatkan rerata dalam kategori baik dan sangat baik

\section{SARAN}

Perlu dilakukan penelitian lebih lanjut mengenai inovasi berbagai aspek yang menyangkut pengembangan kepedulian lingkungan yang melibatkan teknologi agar dapat melatih hardskill sekaligus softsikll dan sejalan dengan perkembangan jaman.

\section{DAFTAR PUSTAKA}

Akbar, A. A. (2017). Akbar, A. A., Sartohadi, J., Djohan, T. S., \& Ritohardoyo, S. (2017). Erosi Pantai, Ekosistem Hutan Bakau dan Adaptasi Masyarakat Terhadap Bencana Kerusakan Pantai Di negara Tropis (Coastal Erosion, Mangrove Ecosystems and Community Adaptation to Coastal Disasters in Tropical Countries). Jurnal Ilmu Lingkungan, 15(1), 1-10.

Akhmedova. 2016 .Educational Tourism,Defining The Concept, Public Administration. Republik Ukraine

Amir, M. F. (2015). Pengaruh Pembelajaran Kontekstual Terhadap Kemampuan Pemecahan Masalah Matematika Siswa Sekolah Dasar. In Prosiding Seminar Nasional Pendidikan (pp. 34-42).

Bungin, Burhan.2015. Analisis Data Penelitian Kualitatif. Jakarta: Raja Grafindo Persada

Hastutiningsih, T., Prasetyo, A. P. B., \& Widiyaningrum, P. (2016). Pengembangan Panduan Pembelajaran Outdoor Bermuatan Karakter Peduli Lingkungan Pada Materi Ekologi. Journal of Innovative Science Education, 5(1), 28-35.

International Career Studies. https://internationalcareerstudies.com/edutourism. Diakses pada tanggal 16 Agustus 2019.

Iswari, Rizky Dewi, and Suyud W. Utomo, 'Evaluasi Penerapan Program Adiwiyata Untuk Membentuk Perilaku Peduli Lingkungan Di Kalangan Siswa (Kasus: SMA Negeri 9 Tangerang Selatan dan MA Negeri 1 Serpong)', Jurnal Ilmu Lingkungan, 15 (2017), 35

Mahadewi, Ni Made Eka. (2018). Nomadic Tourism, Wisata Pendidikan, Digitalisasi Dan Wisata Event Dalam Pengembangan Usaha Jasa Akomodasi Homestay Di Destinasi Wisata. Sekolah Tinggi Pariwisata Nusadua Bali.

Mappanganro, F., Asbar, A., \& Danial, D. (2020). INVENTARISASI KERUSAKAN DAN STRATEGI REHABILITASI HUTAN MANGROVE DI DESA KEERA KECAMATAN KEERA KABUPATEN WAJO. Jurnal Pendidikan Teknologi Pertanian, 4, 1-11. 
Martuti, NKT, dkk. (2018). Peran Kelompok Masyarakat dalam Rehabilitasi Ekosistem Mangrove di Pesisir Kota Semarang. Jurnal Wilayah dan Lingkungan. Volume 6 Nomor 2 hal 100-114.

Muchtar, Z, Rosalia, AVA \& Silaban, S 2019, 'Implementation of dubido based on contextual in improving students achievement on rate reaction', Journal of Physics: Conference Series, vol. 1462, pp. 012053.

Mu'alimah Hudatwi, D. V., \& Putri, A. K. (2019). EDUWISATA HUTAN MANGROVE DESA KURAU TIMUR. In Prosiding Seminar Hukum dan Publikasi Nasional (Serumpun) (Vol. 1, No. 1, pp. 342-345).

Noviani, D. (2015). Implementasi Pembelajaran Berbasis Proyek dalam Meningkatkan Karakter Peduli Lingkungan Pada Peserta Didik Kelas XI Di SMA Negeri 1 Kersana Kabupaten Brebes (Doctoral dissertation, UNIVERSITAS NEGERI SEMARANG).

Perdana, Novrian Satria, 'Implementasi Peranan Ekosistem Pendidikan Dalam Penguatan Pendidikan Karakter Peserta Didik', Jurnal Refleksi Edukatika, 8 (2018), 183-91

PITALOKA, N. W. (2019). EDUTOURISM PUSPA LEBO KABUPATEN SIDOARJO (Studi Deskriptif Tentang Edutourism Puspa Lebo Sebagai Alternatif Objek Wisata Di Kabupaten Sidoarjo) (Doctoral dissertation, Universitas Airlangga).

Putri,M.R.(2018).https://www.republika.co.id/berita/ekonomi/makro/18/01/10/p2bu1r 382kementerian-Ihk-sebut-181-juta-hektare-mangrove-rusak， 16 Agustus 2019.

Ramdani, E. (2018). Model pembelajaran kontekstual berbasis kearifan lokal sebagai penguatan pendidikan karakter. JUPIIS: Jurnal Pendidikan Ilmu-Ilmu Sosial, 10(1), 1-10.

Santoso, E. (2017). Penggunaan Model Pembelajaran Kontekstual Untuk Meningkatkan Kemampuan Pemahaman Matematika Siswa Sekolah Dasar. Jurnal Cakrawala Pendas Vol 3 No.1. hal 16-29.

Schaduw, JNW. (2018). Distribusi dan Karakterisitik Kualitas Perairan Ekosistem Mangrove Pulau Kecil Taman Nasional Bunaken. Fakultas Perikanan dan Ilmu Kelautan,Universitas Sam Ratulangi, Manado,Sulawesi Utara, Indonesia. Majalah Geografi Indonesia Vol 32, No. 1, hal 40-49.

Sugiyono. (2017). Metode Penelitian Kuantitatif, Kualitatif, dan R\&D. Bandung : Alfabeta, CV.

Sukron, F. (2017). Implementasi Pendidikan Karakter Peduli Lingkungan Melalui Program Adiwiyata di SD N KotaGede 3 Yogyakarta. UIN Sunan Kalijaga: Yogyakarta.

Sulistiana, I dan Valeriani, D. (2018). Memberdayakan Masyarakat dan Potensi Desa Sebagai Edutourism di Kemuja Kabupaten Bangka. Program Studi Ekonomi Fakultas Ekonomi Universitas Bangka Belitung.

Tamara, R. M. (2016). Peranan Lingkungan Sosial Terhadap Pembentukan Sikap Peduli Lingkungan Peserta Didik Di Sma Negeri Kabupaten Cianjur. Jurnal Geografi Gea, 16(1), 44-55. 
Tefarani, R., Martuti, N. K. T., \& Ngabekti, S. (2019). Keanekaragaman spesies mangrove dan zonasi di wilayah Kelurahan Mangunharjo Kecamatan Tugu Kota Semarang. Life Science, 8(1), 41-53.

Thiagarajan and Semmel \& Semmel. (1974). Instructional development for training teacher of exceptional children, Bloomington Indiana: Indiana University.

Trinanda, T. C. (2017). Pengelolaan Wilayah Pesisir Indonesia dalam Rangka Pembangunan Berbasis Pelestarian Lingkungan. Matra Pembaruan. 